\title{
Report of two cases with autoerythrocyte sensitization syndrome
}

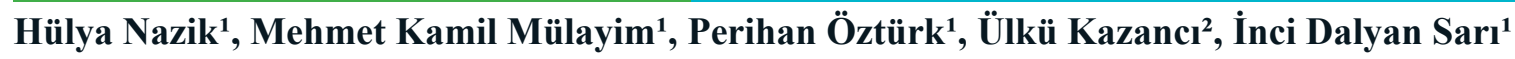

${ }^{1}$ Kahramanmaraş Sütçü Imam University, Department of Dermatology, Kahramanmaraş, Turkey

${ }^{2}$ Kahramanmaraş Sütçü Imam University, Department of Pathology, Kahramanmaraş, Turkey

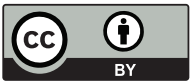

This work is licensed under Creative Commons Attribution 4.0 International License

Received: 2018-11-23

Accepted: 2018-11-27

UDC: 616.1

J Clin Med Kaz 2018; 4(50):40-43

Corresponding Author: Hülya Nazik, MD,

Kahramanmaraş Sütçü İmam University, Department

of Dermatology, Kahramanmaraş, 46100, Turkey.

Phone:+90 (505) 501 9161. Fax:+90 (344) 3003434

E-mail: dr.hulyagul@hotmail.com

\section{Abstract}

Auto-erythrocyte Sensitization Syndrome, also known as Gardner Diamond syndrome, is characterized by spontaneous painful and repetitive purpura. Here, we report two women aged 14 and 18 years who were diagnosed with auto-erythrocyte sensitization syndrome by typical laboratory, clinical, histopathological features and intradermal skin test. Burning and itching were the major complaints associated with spontaneous ecchymosis. The frequency of attacks in the patient using a specific serotonin re-uptake inhibitor due to migraine was significantly higher than the patient who did not receive psychiatric treatment. It was concluded that careful psychiatric evaluation is important for effective treatment of the disease.

Key words: autoerythrocyte sensitization syndrome, Gardner Diamond syndrome, psychogenic purpura

\section{АУТОЭРИТРОЦИТАРЛЫ СЕНСИТИЗАЦИЯ СИНДРОМЫНЫН ЕКІ КЛИНИКАЛЫК ЖАҒДАЙЫНЫН СИПАТТАМАСЫ}

Хулия Назик, ${ }^{1}$ Мехмет Камиль Муляйим ${ }^{1}$, Перихан Озтюрк ${ }^{1}$, Улькю Казанчи $^{2}$, Инчи Дальян Сари ${ }^{1}$

'Имам сутчу Кахраманмараш университеті, дерматология кафедрасы, Кахраманмараш, Түркия

${ }^{2}$ Имам сутчу Кахраманмараш университеті, патология кафедрасы, Кахраманмараш, Түркия

\section{ТҰЖЫРЫМДАМА}

Аутоэритроцитарлы сенситизация синдромы, сондай-ақ Гарднер-Даймонд синдромы ретінде белгілі, ол кенет ауыршандық және мерзімді қызылкүрең түспен сипатталады. Бұл зерттеуде біз 14 және 18 жастағы екі әйелдің клиникалық жағдайларын сипаттаймыз, оларға зертханалық, клиникалық, гистопатологиялық зерттеулер және тері ішілік сынама арқылы аутоэритроцитарлы сенситизация синдромы диагностикаланған. Ашу және қышу кездейсоқ экхимоздан туындаған негізгі шағымдар болды. Серотонинді кері басып алудың селективті тежегішін қабылдайтын пациентте ұстамалардың жиілігі бас ауруына байланысты психиатриялық емдеуге ұшырамаған пациентке қарағанда айтарлықтай жоғары болды. Біз дұрыс психиатриялық баға ауруды тиімді емдеу үшін маңызды деген қорытындыға келдік.

Негізгі сөздер: аутоэритроцитарлы сенситизация синдромы, Гарднер-Даймонд синдромы, психотектік пурпура

\section{ОПИСАНИЕ ДВУХ КЛИНИЧЕСКИХ СЛУЧАЕВ СИНДРОМА АУТОЭРИТРОЦИТАРНОЙ СЕНСИТИЗАЦИИ}

Хулия Назик, ${ }^{1}$ Мехмет Камиль Муляйим ${ }^{1}$, Перихан Озтюрк ${ }^{1}$ Улькю Казанчи ${ }^{2}$, Инчи Дальян Сари ${ }^{1}$

'Университет Кахраманмараш Сутчу Имам, Кафедра дерматологии, Кахраманмараш, Турция

${ }^{2}$ Университет Кахраманмараш Сутчу Имам, Кафедра патологии, Кахраманмараш, Турция

\section{PEЗЮME}

Синдром аутоэритроцитарной сенситизации, также известный как синдром Гарднера-Даймонда, характеризуется спонтанной болезненной и периодической пурпурой. В данном исследовании мы описываем клинические случаи двух женщин 14 и 18 лет, которым диагностировали синдром аутоэритроцитарной сенситизации путем обычных лабораторных, клинических, гистопатологических исследований и внутрикожной пробы. Жжение и зуд были основными жалобами, вызванными спонтанным экхимозом. Частота приступов у пациента, принимающего СИОЗС (селективный ингибитор обратного захвата серотонина) в связи с мигренью была значительно выше, чем у пациента, который не подвергался психиатрическому лечению. Мы пришли к выводу о том, что правильная психиатрическая оценка важна для эффективного лечения болезни.

Ключевые слова: Синдром аутоэритроцитарной сенситизации, синдром Гарднера-Даймонда, психогенная пурпура 


\section{Introduction}

Auto-erythrocyte Sensitization Syndrome (OSS), also known as Gardner Diamond syndrome, is characterized by spontaneous painful and repetitive purpura. In this disease, which often affects young women, lesions can be seen all over the body and are triggered by psychogenic stress or minor trauma [1]. It is thought that the disease is an autoimmune vasculopathy associated with sensitization to erythrocyte membrane containing phosphatidylserine [2]. In this report we present two rare cases with autoerythrocyte sensitization syndrome.
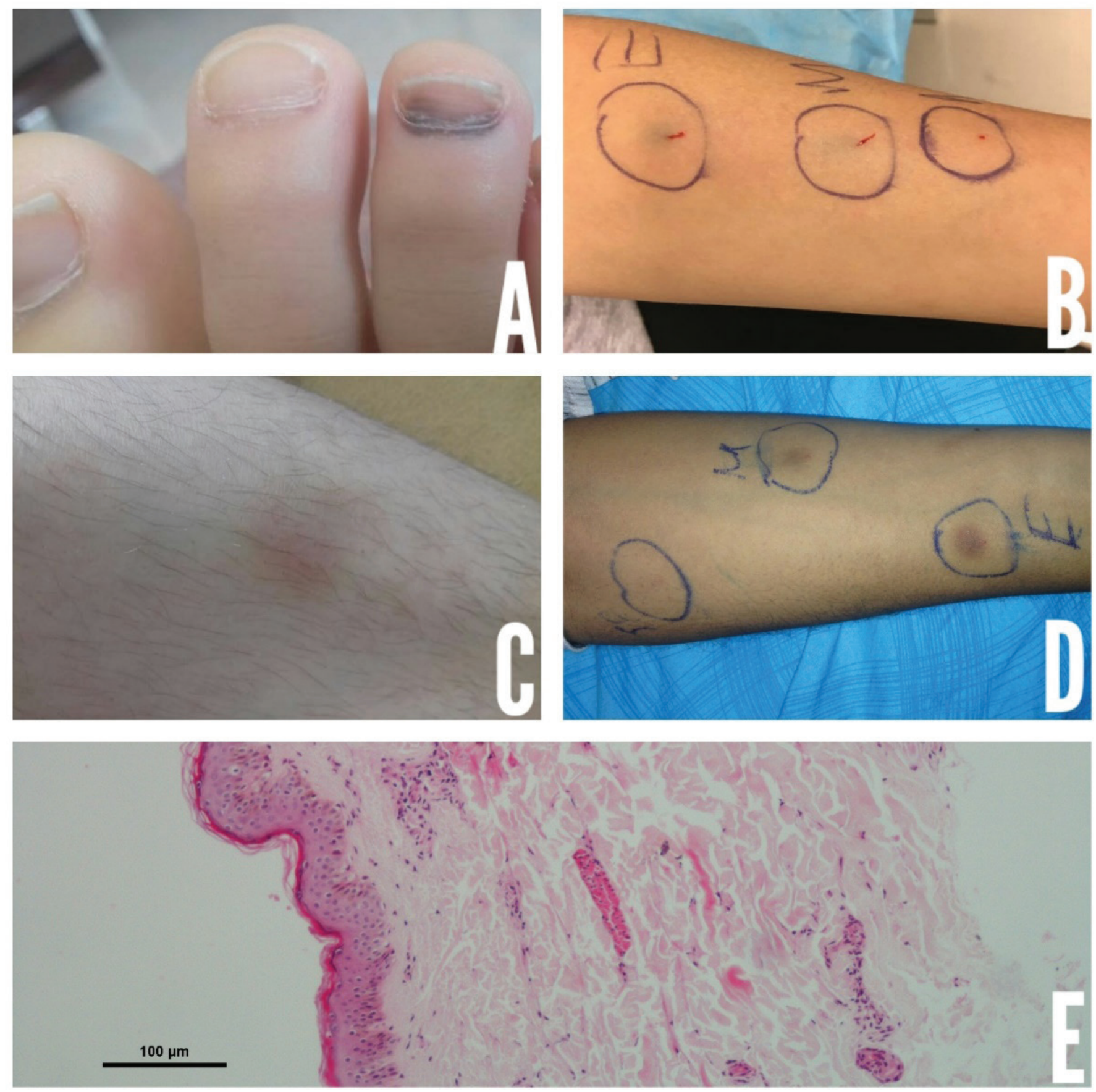

Figure 1 - Specific characteristics of cases: (A) Ecchymosis in the nail bed of Case 1; (B) Result of intradermal skin test in Case 1; (C) Ecchymosis on leg front of Case 2; (D) Result of intradermal skin test in Case 2; (E) Erythrocyte extravasation in the dermis and a mixed type cell infiltration in the perivascular-interstitial area in the pathology of Case 1 (HE, x100) 
and the patient was using a fluoxetine hcl, a selective serotonin reuptake inhibitor (SSRI), for migraine. The patient who has no other drug use did not describe trauma and emotional stress.

The patient had menstruation for two years and did not describe menorrhagia or metrorrhagia. As a result of the evaluation of blood samples taken from the patient, platelet count, prothrombin time, activated partial thromboplastin time and other routine biochemical parameters were in the normal range. Antinuclear antibodies which may be associated with autoimmune diseases, anti-double stranded DNA and anti cardiolipin antibody were negative. The $\mathrm{C}$-reactive protein values $\mathrm{C} 3$ and $\mathrm{C} 4$ values were normal.

The punch biopsy specimen from the most recent lesion was evaluated histopathologically, the results showed mixed type cell infiltration and erythrocyte extravasations with eosinophil and leukocyte in the perivascular and interstitial area under epidermis with mild hyperkeratosis and sparse apoptotic keratinocytes (Figure 1E). Intradermal skin test was performed to the patient who was thought to have OSS. $3 \mathrm{ml}$ venous blood sample from the patient was separated by centrifugation. On the patient's inner forearm three points were determined and $0.1 \mathrm{ml}$ of saline was intradermally applied to the first of the three points, $0.05 \mathrm{ml}$ of saline and $0.05 \mathrm{ml}$ of venous blood (mix) was applied to the second one and $0.1 \mathrm{ml}$ venous blood to the third one. At the end of the 24-hour follow-up, painful ecchymosis occurred in the test areas where the venous blood and venous blood-saline mixture was applied, whereas the test was negative in the area where saline was applied (Figure 1B). As a result of psychiatric examination it was reported that no pathology was determined and continuation of the medical treatment was recommended.

\section{Case 2}

An 18-year-old female patient presented to our clinic with recurrent painful bruising on the forearms and legs for about 1 year. She expressed that her complaints suddenly appeared, that they were recurrent every few weeks accompanied by a severe itching (Figure 1C). She did not benefit from various antihistamines, topical and systemic steroid therapies. She had no known disease in her medical history and did not describe a similar disease in her family history. Etiologically, emotional stress was detected in the patient and it was stated that she did not receive any medical treatment. There was no finding in the evaluation of blood samples taken from the patient. Histopathological evaluation could not be performed since the patient did not approve the biopsy. Intradermal skin test resulted in painful itchy ecchymosis in the test areas where venous blood and venous blood-saline mixture was applied (Figure 1D). Anxiolytic treatment was started as a result of the psychiatric evaluation of the patient.

\section{Discussion}

OSS, also known as psychogenic purpura, is a rare condition characterized by the formation of spontaneous and painful skin lesions that develop into ecchymosis following episodes of severe physiological or psychological stress [3]. Although the etiology of the disease is not known exactly, it is seen that it has a psychological component. It can be associated with psychiatric diagnoses such as depression, anxiety, obsessive-compulsive personality disorder and bipolar disorder. In cases where there is no accompanying psychiatric disorder, there are often symptomatic exacerbations following negative life experiences and excessive psychological stress [4]. While Case 1 did not describe emotional stress, case 2 described emotional stress.
However, we think that SSRI treatment that Case 1 has been using for 3 years due to migraine may have masked the underlying psychiatric condition. Episodes in the disease classically begin with erythema and itching. Lesions develop within 24 hours after the onset of complaints. It has been reported that other systemic symptoms such as nausea, weakness, arthralgia, severe headaches and abdominal pain accompany ecchymosis in OSS [5]. While the dominant complaint was burning in case 1, the dominant complaint in Case 2 was itching. Case 1 described weakness whereas case 2 had no additional complaints.

The majority of OSS cases are young adolescent and adult women, as it is also reported in this study. It is not known why the situation primarily affects women. In one study, especially hormonal effects originating from estrogen are suggested to play a role in the development of OSS [6]. In addition to psychiatric evaluation for the diagnosis of the disease, hematological or autoimmune diseases should be excluded to explain purpura. No findings were found in the laboratory evaluation of both cases and there was no history of bleeding disorder in their families. Intradermal injection of autologous erythrocytes serves as the gold standard in the diagnosis of OSS and the diagnosis is being confirmed by monitoring the lesion development within 24 hours after injection. In literature, a scale that determines the degree of positivity of the test defined by the size of ecchymosis could not be reached. Although the test is positive in most cases, there are also cases where the reaction does not occur with injection [4]. In this study, both cases showed a positive reaction at varying levels to the intradermal test.

In addition to laboratory examinations and intradermal testing, histopathological evaluation also contributes to the diagnosis. Typical histological results include the presence of perivascular infiltrates of lymphocytes or neutrophils, extravasations of erythrocytes in the dermis and the presence of dermal hemorrhages. In this study, histopathological changes of Case 1 were consistent with the diagnosis. With regard to the duration of the disease, duration of 1 month to 26 years has been reported in literature [7]. There is currently no consensus on the optimal treatment of OSS due to the rarity of the disease. Typical treatment modalities focus on the psychological component of the disorder and include SSRIs, corticosteroids, tricyclic antidepressants and psychotherapy. In this study, the average frequency of attacks was once a month for Case 1 with SSRI treatment and once a week for Case 2. In this case, it can be concluded that treatment of SSRI reduces the frequency of attacks, but it is not sufficient in treatment alone. The treatment is successful when the typically underlying psychiatric problems are resolved and when supportive measures are taken for dermatological symptoms [4]. In this study, after a 6-month follow-up it was observed that the frequency of complaints decreased in Case 2 after an anxiolytic treatment of Case 2, but there was no change in the course of the disease in Case 1.

As a result, OSS diagnosis should be considered in the presence of ecchymosis accompanied by complaints such as burning and itching, especially in female cases. For the effective treatment of the disease, we think that careful psychiatric examination will contribute to the treatment.

Disclosures: There is no conflict of interest for all authors. Patient informed consent: obtained. 


\section{References}

1. Ivanov OL, LvovAN, MichenkoAV, Künzel J, MayserP, GielerU.Autoerythrocyte sensitization syndrome(Gardner-Diamond syndrome): review of the literature. J Eur Acad Dermatol Venereol. 2009; 23(5):499-504. https://doi.org/10.1111/j.1468-3083.2009.03096.x

2. Özuğuz P, Polat S, Kaçar SD. Autoerythrocyte Sensitization Syndrome: A Case Report. Clin Anal Med. $2014 ; 5$ (suppl 2):160-2.

3. Gardner F, Diamond L. Autoerythrocyte sensitization: a form of purpura producing painful bruising following autosensitization to red blood cells in certain women. Blood. 1995; 10:675-690.

4. Block ME, Sitenga JL, Lehrer M, Silberstein PT. Gardner-Diamond syndrome: a systematic review of treatment options for a rare psychodermatological disorder. Int J Dermatol. 2018 Sep 20.https://doi.org/10.1111/ijd.14235

5. Tainwala RR, Phiske M, Raghuwanshi A, Mathapati S, Manjare AK, Jerajani HR. Perplexing purpura in two females: Rare case of autoerythrocyte sensitization syndrome. Indian Dermatol Online J. 2013;4(4):305-8. https://doi.org/10.4103/2229-5178.120650

6. Durmazlar SP, Atacan D, Cemil B, Eskioglu F. Is Gardner-Diamond syndrome associated with hormonal influences along with psychosocial problems? A delayed diagnosis. Eur J Dermatol. 2009; 19(3):259-60. https://doi.org/10.1684/ejd.2009.0624

7. Kavala M, Südoğan S, Büyük AY, Aksakal A, Sarıül Ş, Eskiçırak B. Autoerythrocyte sensitization syndrome: Gardner-Diamond syndrome. Turkderm. 2003; 37:120-123.

How to cite this article: Hülya Nazik, Mehmet Kamil Mülayim, Perihan Öztürk, Ülkü Kazanc1, İnci Dalyan Sarı. Report of two cases with autoerythrocyte sensitization syndrome. J Clin Med Kaz. 2018; 4(50):40-43 